DOI https://doi.org/10.18551/rjoas.2021-02.15

\title{
INCREASING PRODUCTIVITY OF THE LEAD CONTAMINATED PADDY SOIL BY USING HUSK BIOCHAR AND AZOLLA IN DAGANG KELAMBIR VILLAGE TJ. MORAWA INDONESIA
}

\author{
Hidayat B.* \\ Doctoral Program of Agricultural Sciences, Faculty of Agriculture, \\ University of Sumatera Utara, Indonesia \\ Rauf A., Sabrina T. \\ Program Study of Agrotechnology, Faculty of Agriculture, University of Sumatera Utara, \\ Indonesia \\ Jamil A. \\ Indonesia Quarantine of Agriculture, Jakarta, Indonesia \\ *E-mail: bendayat@gmail.com
}

\begin{abstract}
Lead $(\mathrm{Pb})$ is an element that is commonly used in various industries and is always present in various forms of the pollution, whether solid, liquid or gas (air), efforts to reduce Lead levels are very necessary considering this metal has many sources both naturally and as factory residue, fertilizers and pesticides. This research aims to restore and increase the productivity of the polluted rice fields by producing $\mathrm{Pb}$-free rice. This study used a 2-factor randomized block design with 4 replications, the first factor was Biochar application; without Biochar (B0) and with Biochar rice husk (B1). The second factor using Azolla, namely; without Azolla (A0), with Azolla pinnata (A1) and Azolla mycrophylla. The results showed that giving Biochar rice husk and Azola was able to increase production up to 7.10 tons / ha, up $10 \%$ from control and reduce lead to $43.9 \%$ and the best azolla for paddy lead contaminated was Azolla mycrophylla.
\end{abstract}

\section{KEY WORDS}

Paddy, lead, productivity, biochar, azolla.

Sustainable wetland management and increased production are challenged by the emergence of degraded paddy fields, reduced the quality and productivity of the land, and there are also many conversions of paddy fields to plantations promised large income for farmers, hence becomes a concern about rice food shortages and has become the national goal for rice self-sufficiency in Indonesia (Sulaiman et al. 2019).

The emergence of the factories in agricultural areas, especially in rice fields, and excessive use of the agrochemical fertilizers which contain lots of compounds containing heavy metals, especially lead $(\mathrm{Pb})$, have become a concern of the metal contamination in lowland rice, as many have reported, would have a negative effect on human (Sulaiman et al. 2019)

Lead has a terrible impact on humans when crosses the threshold $(10-25 \mu \mathrm{g} / 100 \mathrm{ml})$, especially for children. Among them are affecting cognitive function, learning ability, shortening height, decreasing hearing function, affecting behavior and intelligence, damaging the function of organs, such as the kidneys, nervous system, and reproduction, increasing blood pressure and affecting brain development. It could also cause anemia (Sudarmaji et al. 2006).

Biochar is the product of biomass which undergoes a thermolysis process so that it changes the carbon structure to become aromatic and resists the decomposition process for a long time and becomes a long-term carbon storage. Biochar has wide pores, the best place for increased bacterial activity, fungi that produce a lot of organic acids (Tumuluru, 2011), the 
ability of biochar to absorb $\mathrm{CO}_{2}$, carbonates, bicarborbonates and high content of alkaline cations which could be exchanged to make biochar has the best ability to absorb heavy metals (Park et al. 2011; Cui et al. 2011; Jiang et al. 2012; Moo et al. 2013; Ferreiro, 2014; Xu et al. 2016)

Biochar has properties like organic matter, has a variable charge, the functional group of organic matter could be positively or negatively charged depending on soil $\mathrm{pH}$, therefore the ability to absorb cations also changes depending on the load on the soil complex (Havlin et al. 2005). He also reported that liming increases soil pH from 4.20-5.99, increases the availability of $\mathrm{Ca}$ and $\mathrm{Mg}$, and the utilization of biochar also has similarities with calcite lime, because biochar has a $\mathrm{pH}$ between 8.5 and 9 with a high alkaline content could be used to increase $\mathrm{pH}$ (Hidayat, 2017).

Organic carbon biochar is resistant to weathering processes, biochar could last a long time in the soil, adding biochar could increase production by improving soil physical, chemical and biological properties (Chan et al. 2009), and widely reported that biochar increases soil pH and cation exchange capacity. (Liang et al. 2006). Biochar also contributes negative ions to the soil, and ions could act as a buffer for the soil so that its application could increase the efficiency of nitrogen fertilization (Chan et al. 2009).

Rice husk biochar has a fairly wide surface area and is very porous, and has a variable charge hance has a buffer effect on high-pH soils, and the rice husk given was $3.3 \%$ weight could reduce alkaline soil pH (Shrestha, et al. 2019).

Rice husk biochar is also able to increase land productivity and fertilizer efficiency, as reported by Slavich et al (2011) that rice husk biochar increases land productivity in Aceh from 4.01 tonnes / ha to 6.82 tonnes / ha with an increase in the efficiency of $\mathrm{N}$ fertilization from 20.7 - 24.6 dry grain / kg N in agriculture 2010-2011.

Azolla is a fern plant that is rich itrogen when applied continuously to paddy fields, able to replace the use of urea with a nutrient supply of up to $4-60 \mathrm{~kg} /$ ha equivalent, and could increase land productivity (Talley et al. 1981; Kannaiyan 1982)

There are several species of azolla, namely; Azolla pinnata, Azolla mycrophylla, Azolla Filiculoides, Azolla caroliniana, Azolla mexicana, Azolla Africana, Azolla nilotica. Azolla rubra $\mathrm{R}$. Br and commonly found in Asia are Azolla pinnata and Azolla microphylla, both commonly used as bioferlizers, and Azolla microphylla are the most active species at high temperatures $\left(38^{\circ} \mathrm{C}\right)$ (Kannaiyan 1982)

Besides having the ability to supply azolla nutrients, it also has the ability to absorb heavy metals Pb, Cd, Cu, Ni, Zn (Rakhshaee et al. 2006; Ganji et al 2005), Cr (Arora et al. 2006), Cs, Sr (Mashkani and Ghazvini, 2009), Hg (Bennicelli et al. 2004). This ability is due to the presence of pectin in specific vacuums in azolla which contains phtochelatin protein which has the ability to absorb heavy metals.

Arora et al. 2006, conducted tests on several types of azolla to find out which one is the best for absorbing $\mathrm{Cr}$, from the results of the study it was found that Azolla microphylla had a higher $\mathrm{Cr}$ absorption ability than Azolla pinnata and Azolla filiculoides at $14931 \mathrm{ppm}$ with a BCF value of 4167.

The large potential for the use of biochar rice husk and azolla in remediating contaminated rice fields so as to achieve maximum production, it is necessary to seek the utilization technology to improve the quality and quantity of $\mathrm{Pb}$ contaminated paddy field production.

\section{METHODS OF RESEACH}

This research was conducted in farmers' land in Dagang Kelambir Village, Tanjung Morawa Indutrial Area, with high Pb consentration (Simangunsong, 2009) an altitude of $25 \mathrm{M}$ above sea level, with inceptisol soil types (Fig.1) and analysis in the BPTP laboratory Indonesia Standart Commitee. This research was started in July-February 2015. The biochar material of rice husk was terminated with BT 01 tool. The tools used were the couldgkuk and Jetor for processing soil, sickle, jetor and thaser thresher rice, wood and labels for pancouldg samples. The pyrolyzer is a drum that has a hole at the bottom and is given an inlet and 
outlet and is given a water cooler so that the ash content is not high. The materials used are Azolla pinnata and Azolla microphylla, Urea, SP36 and KCl as basic fertilizers and others.

This study used a factorial randomized block design method with selected treatment of the results of the first stage research, namely:

Biochar factor (B), consists of two types; Without Biochar (B0), Biochar rice husk (B1). Azolla factor $(A)$, consists of two types; Without azolla (A0), Azolla pinnata,(A1), Azolla microphylla (A2).

The nursery is prepared 25-30 days before planting, and the seeds are sown over the prepared nursery. Five days after sowing, the nursery is watered about $1 \mathrm{~cm}$ high for two days, and water continuously as high as $5 \mathrm{~cm}$. occasionally the nursery needs to be dried hance the roots are not too long. Seedlings can be transplanted after 15-17 days after sowing and planted with a tile system and spacing $20 \times 20 \mathrm{~cm}$

Biochar was given according to the treatment in 1 day incubation until the water was implanted into Biochar, and given 100 grams of azolla, grown for 2 weeks until the plot surface was covered with azolla. 10 samples were made randomly after the rice was 1 month growth. Parameter observed ware $\mathrm{pH}$, organic Carbon, $\mathrm{Pb}$ - total and available, Number of productive tillers (stems), Number of Grain Contains / Panicles (grain), 1000 grain weight (g), milled dry grain (GKG) (kg / Ha), Consentration $\mathrm{Pb}$ in husk and milled.

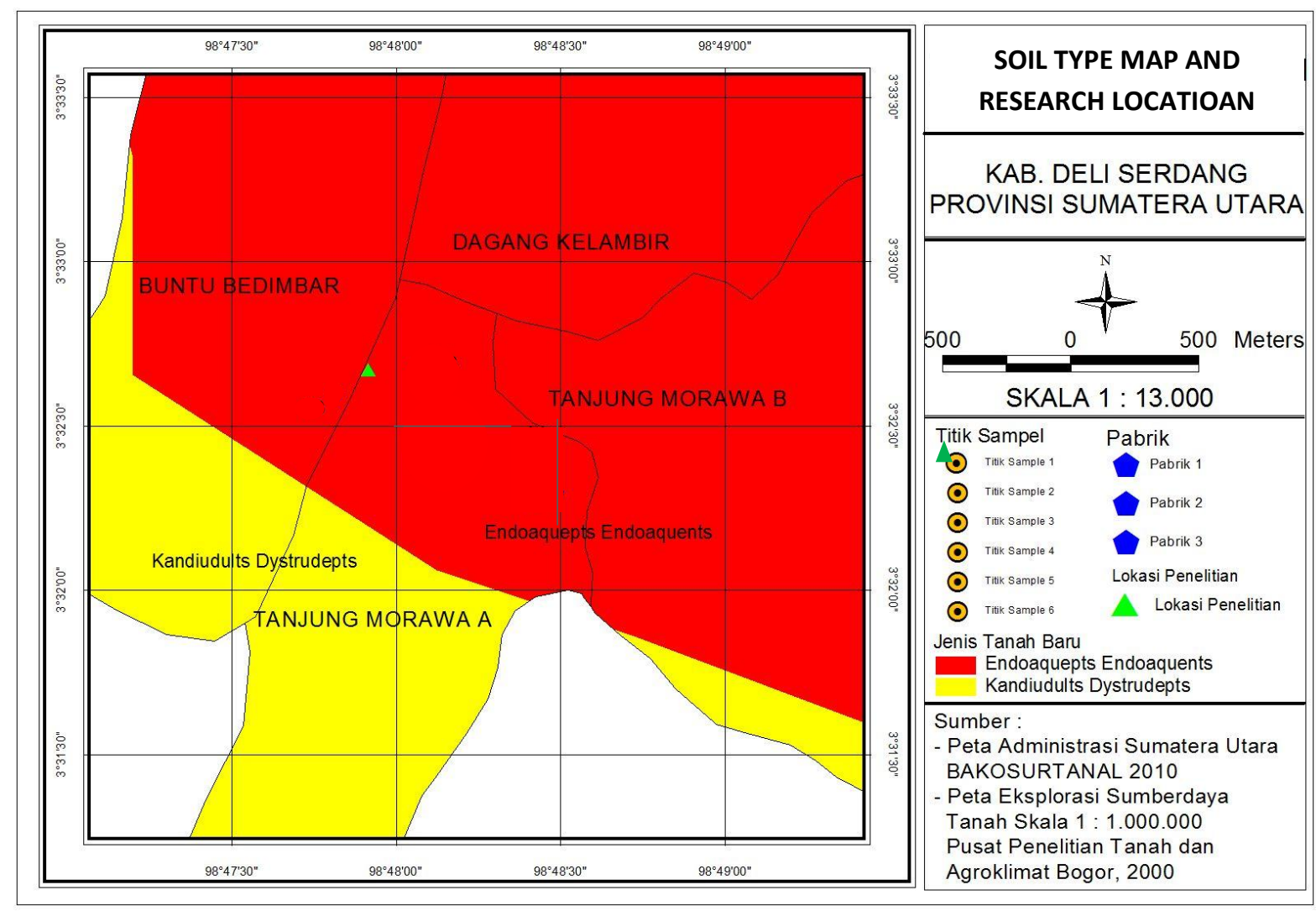

Figure 1 - Soil type map and research location

\section{RESULTS AND DISCUSSION}

The application of biochar and azolla had no significant effect on changes in soil $\mathrm{pH}$ in $\mathrm{Pb}$-contaminated rice fields (Table 1). Provision of biochar tended to increase soil pH even though it was not statistically significant and the highest $\mathrm{pH}$ was in the rice husk biochar treatment at 6.69 and the lowest was in the control at 6.67.

The application of azolla had no significant effect with the highest $\mathrm{pH}$ in the treatment of Azolla pinnata (A1) at 6.69 which was not significantly different from the control and the lowest was in the treatment of Azolla mycrophylla (A2) at 6.66. 
Table 1 - Application biochar and azolla on Soil pH in Soil Pb contaminated

\begin{tabular}{lllll}
\hline Treatments & A0 (With out Azolla) & A1 (Azolla pinnata) & A2 (Azolla microphylla) & Average \\
\hline B0 (With out Biochar) & 6,68 & 6,68 & 6,65 & 6,67 \\
B1 (Husk Biochar) & 6,70 & 6,70 & 6,68 & 6,69 \\
\hline Average & 6,69 & 6,69 & 6,66 & 20,04 \\
\hline
\end{tabular}

The interaction of biochar and azolla had no significant effect on changes in soil $\mathrm{pH}$, with the highest value on the interaction of rice husk biochar and azolla mycrophylla (B1A2), valued at 6.68 and the lowest value on the treatment of rice husk biochar and Azolla pinnata (B1A1) at 6, 70 and the two were not significantly different from the controls. Provision of biochar tends to increase the $\mathrm{pH}$ due to the presence of alkaline cations which give a liming effect but this property is reduced due to the polarity of the water which attracts each other towards two different poles so that the more water supplied will have an effect on $\mathrm{pH}$ neutralization (Hillel, 1980).

The application of biochar and azolla in general had a significant effect on soil organic carbon content in $\mathrm{Pb}$-polluted rice fields (Table 2). The application of biochar tended to increase soil organic carbon although statistically it had no significant effect, giving biochar increased organic carbon from 1.60 (control) to 2.02 in the rice husk biochar treatment (B1).

Giving Azolla is a very real effect on improving soil organic carbon, with the highest value in the treatment of Azolla microphylla (A2) amounting to $2.30 \mathrm{ppm}$, and the lowest in treatment Azolla pinnata (A1) worth 1.49 ppm.

Table 2 - Application biochar and azolla on Soil Carbon Concentration in Soil Pb contaminated (\%)

\begin{tabular}{lllll}
\hline Treatments & A0 (With out Azolla) & A1 (Azolla pinnata) & A2 (Azolla microphylla) & Average \\
\hline B0 (With our Biochar) & 1,36 & 1,25 & 2,20 & 1,60 \\
B1 ( Husk Biochar) & 1,90 & 1,74 & 2,42 & 2,02 \\
\hline Average & $1,62 \mathrm{a}$ & $1,49 \mathrm{a}$ & $2,30 \mathrm{~b}$ & 1,81 \\
\hline
\end{tabular}

Note: The numbers followed by the same letter are not significantly different based on the DMRT test at the $5 \%$ level.

Interaction biochar and Azolla provide no real influence on increasing the organic content of the soil, with the highest value on the interaction biochar rice husks and Azolla microphylla (B1A2) worth of $2.42 \mathrm{ppm}$ and the lowest value in the treatment of rice hull biochar and Azolla pinnata (B1A1) worth 1, 74 ppm.

Azolla microphylla has the ability to replicate a 2-3 fold in one week, and Azolla also has a high adaptability so that with this capability could potentially contribute Azolla microphylla organic matter in the soil (Arora and Singh 2002; Hidayat et al 2017).

The application of biochar and azolla had no significant effect on increasing the total $\mathrm{Pb}$ of soil in $\mathrm{Pb}$-polluted rice fields (Table 3). The application of biochar tended to reduce the total soil $\mathrm{Pb}$ although statistically it had no significant effect, giving biochar reduced the total soil $\mathrm{Pb}$ from $63.68 \mathrm{ppm}$ (control) to $63.06 \mathrm{ppm}$ in the rice husk biochar treatment (B1).

The provision of Azolla microphylla reduced the total $\mathrm{Pb}$ by $3.31 \mathrm{ppm}$ compared to the control on $\mathrm{Pb}$ contaminated land although it was not statistically significant, from the value of $64.15 \mathrm{ppm}$ in the control to $61.02 \mathrm{ppm}$ in the rice husk biochar treatment, and giving Azolla pinnata increased the total $\mathrm{Pb}$ value. amounting to $0.79 \mathrm{ppm}$ although statistically not significantly different.

The interaction of biochar and Azolla had no significant effect on the total soil $\mathrm{Pb}$ content, with the highest value on the interaction between rice husk biochar and Azolla pinnata (B1A1) at $67.61 \mathrm{ppm}$ and the lowest value on the treatment of rice husk biochar and Azolla microphylla (B1A2) at 61, 97.

Table 3 - Application biochar and azolla on $\mathrm{Pb}$ - Total Concentration in Soil Pb contaminated (ppm)

\begin{tabular}{lllll}
\hline Treatments & A0 (With out Azolla) & A1 (Azolla pinnata) & A2 (Azolla microphylla) & Average \\
\hline B0 (With out Biochar) & 68,69 & 62,28 & 60,07 & 63,68 \\
B1 (Husk Biochar) & 59,62 & 67,61 & 61,97 & 63,06 \\
\hline Average & 64,15 & 64,94 & 61,02 & 63,37 \\
\hline
\end{tabular}


Preparation of biochar in the pyrolysis process uses high temperatures and lead $\mathrm{Pb}$ in the materials will evaporate, hence the process does not contribute to the material biochar $\mathrm{Pb}, \mathrm{Pb}$ evaporation temperature is $300-400 \mathrm{OC}$ and then form a lead oxide (Palar, 1994)

Giving biochar and Azolla significant effect on the decrease in available soil $\mathrm{Pb}$ in paddy fields contaminated with $\mathrm{Pb}$ (Table 4), the provision of biochar lower the available soil $\mathrm{Pb}$ from $29.05 \mathrm{ppm}$ (control) to $25.18 \mathrm{ppm}$ on rice husk biochar treatment (B1) with a decrease of $3.87 \mathrm{ppm}$.

Azolla application had significant effect on the reduction of $\mathrm{Pb}$ available in $\mathrm{Pb}$ contaminated paddy fields, with the lowest value in the treatment of Azolla microphylla (A2) amounting to $23.34 \mathrm{ppm}$ and the highest in the treatment of Azolla pinnata worth of 29.32 ppm and was not significantly different from controls.

Interaction biochar and Azolla give real influence on the decrease in available $\mathrm{Pb}$ in paddy fields contaminated soil $\mathrm{Pb}$, with the highest available value in the treatment $\mathrm{Pb}$ Biochar rice husks and Azolla pinnata (B1A1) amounting to $27.91 \mathrm{ppm}$ and $\mathrm{Pb}$ values at the lowest available biochar treatment chaff rice and Azolla microphylla (B1A2) valued at 21.55ppm.

Table 4 - Application biochar and azolla on Pb-Available Concentration in Soil Pb contaminated (ppm)

\begin{tabular}{lllll}
\hline Treatments & A0 (With out Azolla) & A1 (Azolla pinnata) & A2 (Azolla microphylla) & Average \\
\hline B0 (With out Biochar) & 31,30 & 30,72 & 25,13 & $29,05 \mathrm{~b}$ \\
B1 (Husk Biochar) & 26,09 & 27,91 & 21,55 & $25,18 \mathrm{a}$ \\
\hline Average & $28,70 \mathrm{~b}$ & $29,32 \mathrm{~b}$ & $23,34 \mathrm{a}$ & 27,12 \\
\hline
\end{tabular}

Note: The numbers followed by the same letter are not significantly different based on the DMRT test at the 5\% level.

The ability of biochar in reducing $\mathrm{Pb}$ available relating to the number of exchangeable base cations and biochar properties similar to organic material which has a variable payload acid and organic acid that can adsorb $\mathrm{Pb}$ available land becomes unavailable (Havlin et al, 2005).

The provision of Biochar and Azolla in general had a significant effect on increasing the production of $\mathrm{Pb}$ contaminated lowland rice in the field (Table 5). Application of the biochar increase rice production of 6.56 tons / ha in the control treatment into biochar 6.81 on rice husk treatment, although not statistically significantly different.

Table 5 - Application biochar and azolla on $\mathrm{Pb}$ - Available Concentration in Soil $\mathrm{Pb}$ contaminated (Tonnes/ha)

\begin{tabular}{lcccc}
\hline Teratments & A0 (With out Azolla) & A1 (Azolla pinnata) & A2 (Azolla microphylla) & Average \\
\hline B0 (With out Biochar) & 6,35 & 6,53 & 6,81 & 6,56 \\
B1 (Husk Biochar) & 6,55 & 6,50 & 7,40 & 6,81 \\
\hline Average & $6,45 \mathrm{a}$ & $6,51 \mathrm{a}$ & $7,10 \mathrm{~b}$ & 6,69 \\
\hline
\end{tabular}

Note: The numbers followed by the same letter are not significantly different based on the DMRT test at the $5 \%$ level.

The application of azolla increased the productivity of $\mathrm{Pb}$ contaminated land significantly, with the highest productivity in the Azolla microphylla (A2) treatment at 7.10 tons / $\mathrm{Ha}$ and the lowest in the control treatment with the value of 6.45 tons / Ha which was not significantly different from the treatment giving Azolla pinnata of 6.51, The production of Azolla microphylla increased by $10 \%$ when compared to controls.

The highest increase in production was found in the interaction treatment of rice husk biochar and Azolla microphylla from 6.35 tonnes / ha in the control to 7.40 tonnes / ha, up $16.53 \%$ and this was very spectacular for the first planting year.

Azolla's ability to increase rice production has long been known (Yadav et al., 2014), but the ability of azolla to increase rice production in polluted land is something very new, this is because azolla is a hyper accumulator plant that has Very high ability to absorb heavy metals without interfering with the physiological process, Hidayat (2011) said that azolla can accumulate 18 times higher than that in the soil, this ability is because there is a special 
protein, namely pythochelatin which plays a role in metal uptake and is stored in special vacuoles so that does not affect the ability of azolla to fix N (Benaroya et al., 2004).

Giving biochar and Azolla generally give impairment $\mathrm{Pb}$ concentration in the husk, although not statistically (Table 6). Provision of rice husk biochar reduces the concentration of $\mathrm{Pb}$ in rice husks in $\mathrm{Pb}$ contaminated rice fields. The lowest concentration value in the rice husk biochar treatment was $2.13 \mathrm{ppm}$, down $0.03 \mathrm{ppm}$ compared to the treatment without biochar.

Table 6 - Application biochar and azolla on Lead Concentration in rice Husk on Soil Pb contaminated (Tonnes/ha)

\begin{tabular}{lllll}
\hline Treatments & A0 (With out Azolla) & A1 (Azolla pinnata) & A2 (Azolla microphylla) & Average \\
\hline B0 (With out Biochar) & 2,43 & 2,33 & 1,71 & 2,16 \\
B1 (Husk Biochar) & 2,14 & 2,53 & 1,73 & 2,13 \\
\hline Average & 2,29 & 2,43 & 1,72 & 2,14 \\
\hline
\end{tabular}

Giving Azolla shows a decrease in $\mathrm{Pb}$ concentration value of rice husk yields in $\mathrm{Pb}$ contaminated soil. The value of the lowest concentration showed in application of the Azolla microphylla valued at $1.72 \mathrm{ppm}$ and no significant difference in treatment Azolla pinnata (2.43 ppm) and without Azolla (2,29ppm).

The application of rice husk biochar and Azolla in general significantly reduced $\mathrm{Pb}$ concentrations in rice harvested in $\mathrm{Pb}$ contaminated land (Table 7). The provision of rice husk biochar reduces the $\mathrm{Pb}$ concentration in the rice harvested in $\mathrm{Pb}$ polluted land, although it is not statistically significant. The lowest concentration was in the rice husk biochar treatment at $13.18 \mathrm{ppm}$ and the highest was in the treatment without Biochar at 14.06.

Table 7 - Application biochar and azolla on Lead Concentration in rice harvested on soil $\mathrm{Pb}$ contaminated (Tonnes/ha)

\begin{tabular}{lllll}
\hline Treatments & A0 (With out Azolla) & A1 (Azolla pinnata) & A2 (Azolla microphylla) & Average \\
\hline B0 (With out Biochar) & 16,28 & 15,32 & 10,59 & 14,06 \\
B1 (Husk Biochar) & 14,78 & 15,64 & 9,13 & 13,18 \\
\hline Average & $15,53 \mathrm{~A}$ & $15,48 \mathrm{~A}$ & $9,86 \mathrm{~B}$ & 13,62 \\
\hline
\end{tabular}

Note: The numbers followed by the same letter are not significantly different based on the DMRT test at the 5\% level.

Application of Azolla on paddy soil contaminated showed a decrease in concentration of $\mathrm{Pb}$ in rice is very real. The lowest $\mathrm{Pb}$ concentration was found in the treatment of Azolla microphylla with a value of $9.86 \mathrm{ppm}$, which was significantly different from that of Azolla pinnata (15.48 ppm) and without Azolla.

The lowest decrease in $\mathrm{Pb}$ concentration in rice was found in the interaction treatment between biochar husk and Azolla microphylla from 16, 28\% in the control to $9.13 \%$, which was a decrease of $43.91 \%$ and this was very spectacular with heterogeneous field conditions.

Azolla mycrophylla's high ability is due to its adaptability and growth rate which is very fast compared to Azolla pinnata (Arora and Singh, 2002; Arora et al 2005), Azolla is able to replicate 2-3 times a week and a very high bioaccumulation capacity of 18 meaning that Azolla mycrophylla absorbs 18 times the concentration more than that in solution (Hidayat, 2011.

\section{CONCLUSION}

The application of biochar and Azolla to $\mathrm{Pb}$ contaminated land increases the productivity of $\mathrm{Pb}$-contaminated rice fields by stabilizing the $\mathrm{pH}$, increasing the soil's organic $\mathrm{C}$ content, stabilizing total $\mathrm{Pb}$, reducing available $\mathrm{Pb}$ of soil, filled grain, 1000 grain weight, and reducing the $\mathrm{Pb}$ content of husk and paddy rice grain. The provision of Biochar rice husk and Azolla microphylla produced the highest production valued at 7.40 tonnes / ha, up $16.54 \%$ and Azolla microphylla significantly increased production to 7.10 tonnes / ha, up 
$11.81 \%$ compared to control treatment. The administration of rice husk biochar and Azolla microphylla resulted in the lowest $\mathrm{Pb}$ concentration in rice from $16.28 \%$ in the control to $9.13 \%$ down $43.91 \%$ from the administration. Azolla microphylla was able to reduce the $\mathrm{Pb}$ concentration significantly to a concentration of $9.86 \%$ down $39,43 \%$.

\section{ACKNOWLEDGMENTS}

The author's appreciation to the Directorate General of Higher Education, Ministry of Research, Technology, and Higher Education of Indonesia. Through the Research Institute of the University of Sumatera Utara, which has provided funding for the Doctor Dissertation Founding

\section{REFERENCES}

1. Arora, A., and Singh, P.K. 2002. Comparison of biomass productivity and Nitrogen Fixing

2. Potential of Azolla SPP. Biomass \& Bioenergi 24 (2003) 175-178.

3. Arora, A., Sudhir, S and Dinesh K.S., 2006. Tolerance ang Phytoaccumulation of Chromium by Three Azolla Species. Word Journal of Microbiologi \& Biotecnology 22:p. 97-100.

4. Benaroya, O.R., Tzin, V., Tel-Or, E., Zamski, E., 2004. Lead accumulation in the aquatic fern Azolla filiculoides. Plant Physiol. Biochem., 42 (7-8): 639-645.

5. Bennicelli, R., Stepniewska Z, Banach A, Szajnocha K, Ostrowski, 2004. The Ability of Azolla caroliniana to remove heavy Metal ( $\mathrm{Hg}(\mathrm{II}), \mathrm{Cr}$ III), $\mathrm{Cr}(\mathrm{VI})$ from municipial Waste Water. Chemosphere 55 (2004) 141-146.

6. Chan, K., and Z, Xu. 2009. Biochar: Nutrient properties and their enhancement.p. 67-84. In J. Lehmann and S. Joseph (ed.) Biochar for environmental management: Science and technology. Earthscan, London.

7. Cui, L., Liangqing, L., Afeng, Z., Genxing, P., Dandan, B., Andrew, C., 2011. Biochar amandment greatly reduces $\mathrm{Cd}$ uptake in contaminated paddy soil: atwo year field experiment. BioResources 6(3), 2605-2618.

8. Ferreiro, J.P., H. Lu., S. Fu1., A. Méndez., and G. Gascó, 2014. Use of phytoremediation and biochar to remediate heavy metal polluted soils. Solid Earth, 5, 65-75, 2014. doi:10.5194/se-5-65-2014.

9. Ganji, MT, M. Khosravi, R. Rakhshaee,. 2005. Biosorption of $\mathrm{Pb}, \mathrm{Cd}, \mathrm{Cu}$ and $\mathrm{Zn}$ from the wastewater by treated Azollafiliculoides with $\mathrm{H}_{2} \mathrm{O}_{2} / \mathrm{MgCl}_{2}$. International Journal of Environmental Science \& Technology Vol. 1, No. 4, pp. 265-271.

10. Hidayat (2011). Hidayat, B. 2011a. Skrining Tumbuhan Tumbuhan air Hiperakumulator. Kultura UMN Alwashliyah. Volume 20 September 2011.

11. Hidayat, B., A. Rauf., T. Sabrina., Ali Jamil, 2017. Evaluation Content of Pb in Phase Vegetative and Generative of Paddy by Aplication Azolla and Husk Biochar in Contaminated Paddy Field. International Journal of Sciences: Basic and Applied Research (IJSBAR) (2017) Volume 31, No 3, pp 156-164.

12. Hillel D., 1980. Fundamental of soil physics. University of Massachusetts. Academic Press. New York.

13. Jiang TY, Jun J, Ren-K X, Zhuo L, 2012. Adsorption of $\mathrm{Pb}(\mathrm{II})$ on variable charge soils amended ith rice-straw derived biochar. Chemosphere 89 (2012) 249-256.

14. Kannaiyan S, M Thanggaraju, dan G Oblisami. 1982. Azolla and rice: Multiplication and use of Azolla biofertilizer for rice production.Coimbatore: Tamil Nadu Agri Univ, pp 1- 56.

15. Liang B., Lehmann J., Solomon D., Kinyangi J., Grossman J., O'Neill B., Skjemstad J.O., Thies J., Luizao F.J., Petersen J., Neves E.G..2006. Black Carbon increases cation exchange capacity in Soil. Soil Science Society of America Journa. Volume 70, Issue5 September 2006, pp. 1719-1730.

16. Mashkani, S.G., Parisa, T., Mohammad, G, 2009. Biotechnological potential of Azolla filiculoides for biosorption of $\mathrm{Cs}$ and Sr: Application of micro-PIXE for measurement of biosorption. Bioresource Technology 100 (2009) 1915-1921. 
17. Moon DH, Jae-WP, Yoon YC, Yong SO, Sang SL, Mahtab A, Agamemnon K, Jeong HP, Kitae B, 2013. Immobilization of lead in contaminated firing range soil using biochar. Environ Sci Pollut Res DOI 10.1007/s11356-013-1964-7

18. Palar. H. 2004. Pencemaran dan toksikologi logam berat. Jakarta: Rineka cipta.

19. Park, J.H., Girish. K. C., Nanthi. S. B., Jae. W. C., Thammared. C. 2011. Biochar reduces the bioavailability and phytotoxicity of heavy metals. Plant Soil (2011) 348:439-451. DOI 10.1007/s11104011-0948-y.

20. Rakhshaee Roohan., Morteza Khosravi., Masoud Ganji., 2006. Kinetic modeling and Thermodynamic study to remove $\mathrm{Pb}$ (II), $\mathrm{Cd}$ (II) and $\mathrm{Zn}$ (II) from aqueous Solution using dead and Living Azolla filiculoides. Journal of Hazardous Material B124 p.120-129.

21. Shrestha, L.k., Mamata, T., Rekha, G.S., Subrata, M., Raja, R.P., and Katsuhiko, A.,2019. Rice Husk-Derived High Surface Area Nanoporous Carbon Materials with Excellent lodine and Methylene Blue Adsorption Properties. 9, 5, 10; doi:10.3390/c5010010, pp.2-13

22. Simangunsong, Y., 2009. Evaluasi Tingkat Pencemaran Tanah Oleh Beberapa Logam Berat di Desa Tanjung Merawa-B Kecamatan Tanjung Merawa Kabupaten Deli Serdang. Departemen Ilmu Tanah Universitas Sumatera Utara.

23. Slavich, P., Anischan, G., Malem McLeod., Chairunas and Deddy Efrandi, 2011. Rice husk biochar increases nitrogen use efficiency of low land rice in Aceh. Asia Fasific Biochar Conference

24. Sudarmaji, J.Mukono, Corie I.P., 2006. Toksikologi Logam Berat B3. Jurnal Kesehatan Lingkungan, Vol. 2, No. 2, Hal 129-142.

25. Sulaiman, A.A., Yiyi, S, and Budiman M., 2019. A Framework for the Development of Wetland for Agricultural Use in Indonesia. Resources 2019, 8, 34; doi:10.3390/resources8010034

26. Talley NS,, E. Lim, and D. W. Rains. 1981. Application of Azolla in Crop Production. J. M. Lyons et al. (eds.), Genetic Engineering of Symbiotic Nitrogen Fixation and Conservation of Fixed Nitrogen, Plenum Press, New York.

27. Tumuluru, J. S., 2011, Review on Biomass Torefaction Process and Product properties and Design of Moving Bed Torrefaction System Model Development", ASABE Annual International, Meeting, Louisville, Kentucky.

28. Xu P, Cai-XS, Xue-Zhu Y, Wen-DX, Qi Zhang, Qiang W, 2016. The effect of biochar and crop straws on heavy metal bioavailability and plant accumulation in a $\mathrm{Cd}$ and $\mathrm{Pb}$ polluted soil. Ecotoxicology and EnvironmentalSafety132(2016)94-100.

29. Yadav, R.K., G. Abrahan., YV, Singh., P.K, Singh., 2014. Advancements in the ulitization of Azolla- Anabaena system in releation to sutaianable agriculture practices. Proc.Indian Natn Sci.Acad 80 No.2 June 2014.pp.301-316. 